\title{
Constructionalization at Work: The Emergence of the Latin Progressive Present Participle / Gerund Construction*
}

\author{
Jasper Vangaever
}

Université de Lille (UMR 8163 STL); University of Ghent (Department of Linguistics); Sorbonne Université (EA STIH). Rue du Barreau BP 60149, 59650 Villeneuve d'Ascq (France); jasper.vangaever@univ-lille.fr

For citation: Jasper Vangaever. Constructionalization at Work: The Emergence of the Latin Progressive Present Participle / Gerund Construction. Philologia Classica 2019, 14 (2), 249-266.

https://doi.org/10.21638/11701/spbu20.2019.206

In Latin, the present participle and the gerund frequently function as the predicate of an adjunct clause. Such clauses are syntactically dependent on a main clause, with which they form a bi-clausal construction. Under specific semantic and pragmatic circumstances, some of these constructions are interpreted based on a pragmatic inference: the main verb, which corresponds to a verb of existence, position, or movement, is deprived of its lexical meaning and acquires a grammatical function, viz. that of presenting the non-finite state of affairs as being in the middle of its realization. The repeated use and propagation of thusly interpreted constructions gave rise to a new construction, the progressive construction. I argue that the emergence of this construction corresponds to a constructionalization process, and that although this process has not been completed within Latin, many instances of the pattern [verb of existence/position/movement + present participle/gerund] instantiate a construction in its own right, viz. different from the bi-clausal construction that gave rise to it.

Keywords: Latin, present participle, gerund, progressive construction, constructionalization, grammaticalization, Diachronic Construction Grammar.

\section{Introduction}

In Latin, the present participle and the gerund frequently function as the predicate of an adjunct clause (Vangaever 2018, 12-15; 26-27). Such clauses are syntactically dependent on another clause, the main clause, with which they form a bi-clausal construction (Lehmann $1988,185-191)$. When the subject of the present participial or gerundial adjunct clause is coreferential with that of the main clause, the present participle is typically marked in the nominative case (1) and the gerund in the bare ablative case (2) (Vester 1983, 102-108; 121).

(1) Hoc sperans legiones tres ex castris educit [...]. (Caes. civ. 1, 43, 3 [1st c. BC])

"Hoping for this, he led three legions out of camp."

(2) Unus homo nobis cunctando restituit rem. (Cic. off. 1, 84 [1st c. BC])

"One man restored the state for us by delaying."

* This research was funded by the ANR/DFG project PaLaFra (ANR-14-FRAL-0006).

1 All translations are mine $-J . V$.

(C) St. Petersburg State University, 2019 
In Republican and Classical Latin, taken here as the period between the 3rd c. BC and the $2 \mathrm{nd}$ c. $\mathrm{AD}$, nominative present participial clauses are sometimes found in combination with a verb of existence (3) or position (4) (Aalto 1949, 75).

(3) Cuius decursum antecedebat rivus, qui ad eorum accessum summam efficiebat loci iniquitatem. Nam palustri et voraginoso solo currens erat ad dextrum. (Bell. Hisp. 29, 2 [1st c. BC])

"Across this valley ran a rivulet, which made the ground extremely awkward for the troops to approach. For to the right it was running on swampy soil full of bog-holes."

(4) [...] Aristaeus nostri genitoris ad undam stat lacrimans [...]. (Verg. Georg. 4, 355-356 [1st c. BC])

"Aristaeus is crying near the waters of our father."

In Late and Early Medieval Latin, taken here as the period between the 3rd and the 10th c. AD, they are also found in combination with a verb of movement (5) (Aalto $1949,75)$.

(5) Ille vero ibat incessanter vociferans hoc illi accidisse ob scelere quod in servum sancti Trudonis perpetrasset. (Vita Trudonis 26 [8th c. AD])

"He was truly continuously shouting that this had happened to him because of the crime that he completed against the servant of saint Trudo."

Bare ablative gerundial clauses are also found in combination with a verb of existence (6), position (7), and movement (8), but only in Late and Early Medieval Latin (Aalto 1949, 75-76; Bertinetto 2000, 562; Haverling 2010, 497).

(6) [...] in monte erat Darius vociferando et congregando multitudinem hostium [...]. (Leo Alex. $2,14[10$ th c. AD])

"Darius was screaming and gathering many enemies on the mountain."

(7) [...] cum prope silvam venisset [...] stetit dux diu cunctando. (Amm. Hist. 17, 1, 8 [4th c. $\mathrm{AD}])$

"When he had come to a forest, the general had been hesitating for some time."

(8) [...] contra illos qui mentiendo vadunt [...]. (Carol. capit. 1a, 810 [9th c. AD])

"Against those who are lying."

In most instances of the pattern [verb of existence/position/movement + present participle/gerund], the verb of existence, position, or movement does not function as the semantic and syntactic main verb of a bi-clausal construction, as do educit and restituit in (1) and (2), but as the auxiliary of a progressive verbal periphrasis (Pinkster 1998, 230; Bertinetto 2000, 561-563; Bertinetto et al. 2000, 538-540; Haverling 2010, 492-497). It has been assumed that the repeated use of such instances has caused the verb of existence, position, or movement to grammaticalize, but that this evolution has taken place in Romance rather than in Latin (Haverling 2010, 492; 497). The Latin instances of the pattern [verb of existence/position/movement + present participle/gerund] are considered "forerunners" (Bertinetto et al. 2000, 538) or "precursors" (Bertinetto 2000, 563) of the Romance con- 
struction, viz. a kind of "experimental substitute" of the synthetic imperfect tense (Pinkster 1998, 234; Haverling 2010, 492-493). Arguments in favor of this hypothesis are the fact that Latin instances of the pattern [verb of existence/position/movement + present participle/ gerund] are very rare until the 3rd c. AD (Eklund 1970, 74; Pinkster 1998, 230; Haverling 2010, 495), strongly influenced by Biblical Greek (Haverling 2010, 492-495), and characteristic of substandard varieties of Latin (Eklund 1970, 74; Pinkster 1998, 230). However, they do appear already in Republican and Classical Latin (Aalto 1949, 75), inter alia in texts written by authors who are not or only little influenced by Biblical Greek and texts written in standard Latin (Amenta 2003, 146-148; Haverling 2010, 495-496). Despite their frequency rise in Late and Early Medieval Latin (Haverling 2010, 496), the assumption that the verb of existence, position, or movement "was first grammaticalized in the individual Romance languages" (Haverling 2010, 492) has not been questioned.

The aim of the present paper is to investigate to which extent the Latin instances of the pattern [verb of existence/position/movement + present participle/gerund] announce the Romance progressive construction. Drawing on the theoretical framework of Diachronic Construction Grammar (Hilpert 2013; Traugott \& Trousdale 2013; Barðdal et al. 2015), I will examine the functional and formal properties of a varied, but restricted number of such instances in order to determine to which extent their functional and formal analysis differs from that of the bi-clausal construction in (1) and (2) and resembles that of the Romance progressive construction.

\section{Theoretical framework}

The present study is grounded in the theoretical framework of Diachronic Construction Grammar (Hilpert 2013; Traugott, Trousdale 2013; Barðdal et al. 2015), which is a relatively recent theory of language change built on Construction Grammar (Goldberg 1995; 2006; Croft 2001).

Construction Grammar is a usage-based theory of language in which the minimal units are called "constructions" (Goldberg 1995, 4; 2006, 3; Croft 2001, 18). Constructions are unique, conventionalized, and arbitrary form-function pairings with different degrees of internal complexity and lexical specificity. For instance, the English prefix pre-combines a specific form and a specific meaning, the combination of which is conventionalized and unique (Goldberg 2006, 5). Similarly, the noun avocado, the idiom give the Devil his due, and the ditransitive construction Subj V Obj1 Obj2, which evokes a transfer of Obj1 to Obj2 by Subj (e.g. he gave her a fish taco), each represent a unique and conventionalized association between a form and a meaning (Goldberg 2006, 5). The inventory of all form-function pairings is called the "constructicon" of a language (Goldberg 1995, 5 ; 2006, 64).

The basic tenet of Diachronic Construction Grammar is that the constructicon of a language constantly "changes over time as new constructions come into being and old constructions fall out of use" (Barðdal, Gildea 2015, 2). According to Traugott and Trousdale $(2013,1)$, there are two ways in which constructions can change: constructional change and constructionalization. Constructional changes are "changes that affect features of an existing construction, e.g. semantics (will- 'intend'> future), morphophonology (will > 'll), collocational constraints (expansion of the way-construction to include verbs denoting actions accompanying creation of a path, e.g. whistle one's way home), etc." 
(Traugott, Trousdale 2013, 1). Constructional changes affect the functional or formal part of an existing construction, but do not lead to the emergence of a new construction. By contrast, constructionalization is the historical process in which both the functional and the formal structure of an existing construction are reanalyzed, and hence it refers to the historical creation of a new form-function pairing (Traugott, Trousdale 2013, 1).

Since language change is triggered by semantic and pragmatic innovation, which can, but need not bring about syntactic, morphological, and/or phonological change (Heine 1993, 54-56), a complete constructionalization process takes place in two phases: the existing or "source" construction undergoes first a series of semantic and pragmatic changes, and then a series of syntactic, morphological, and phonological changes (Barðdal, Gildea 2015, 17-18; Traugott 2015, 55-56). The semantic and pragmatic changes lead to the functional reanalysis of the source construction, the syntactic, morphological, and phonological changes to its formal reanalysis. The result is a new construction, the "target construction", whose functional and formal properties can no longer be derived from either its source construction or its constitutive parts.

Constructionalization is a slow and gradual process allowing for different kinds of functional and formal overlap between a source and a target construction, the synchronic outcome of which is described by Hopper $(1991,22)$ as "layering". The gradualness of a constructionalization process derives from the fact that functional and formal reanalyses are equally slow and gradual, corresponding to what Traugott and Trousdale $(2010,38)$ call "macro-reanalyses". Macro-reanalyses are large-scaled changes which accumulate different small-step changes that are each individually abrupt and punctual, and it is the accumulation of such small-step changes or "micro-reanalyses" that makes macro-reanalyses durative and gradual. Due to the gradualness of a constructionalization process and the synchronic layering of the source and the target construction, the emergence of a new construction often gives rise to what Rosenbach $(2010,154)$ calls "constructional gradience", viz. the situation in which the functional and/or formal analysis of a construction hesitates between that of the source and the target construction.

\section{Hypothesis}

Since new constructions emerge through the functional and formal reanalysis of existing constructions, the question to which extent Latin instances of the pattern [verb of existence/position/movement + present participle/gerund] announce the Romance progressive construction can be answered by comparing their functional and formal properties with those of the bi-clausal construction in (1) and (2), on the one hand, and with those of the Romance progressive construction, on the other hand.

If the functional and formal properties of the Latin instances of the pattern [verb of existence/position/movement + present participle/gerund] are more similar to the biclausal construction in (1) and (2) than to the Romance progressive construction, then their traditional analysis as exploratory "forerunners" (Bertinetto et al. 2000, 538) or "precursors" (Bertinetto 2000, 563) of the Romance construction, viz. a kind of "experimental substitute" of the synthetic imperfect tense (Pinkster 1998, 234; Haverling 2010, 492-493), is confirmed. If, on the contrary, their functional and formal properties are more similar to the Romance progressive construction than to the bi-clausal construction in (1) and (2), then their traditional analysis is infirmed. 
The hypothesis that I will defend is that the Latin instances of the pattern [verb of existence/position/movement + present participle/gerund] have more properties in common with the Romance progressive construction than with the bi-clausal construction in (1) and (2), and that the emergence of the progressive construction is in the first place a Latin development, but one which is completed only in the individual Romance varieties.

\section{Method}

In order to determine to which extent Latin instances of the pattern [verb of existence/position/movement + present participle/gerund] qualify as progressive constructions, it is necessary to determine the functional and formal properties of the bi-clausal construction in (1) and (2) and those of the Romance progressive construction.

The bi-clausal construction in (1) and (2) contains a (usually finite) main clause and a present participial or gerundial adjunct clause. The main verb and the present participle or gerund are used with their lexical meaning and they have their own argument structure. The present participle is marked in the nominative case (or in the accusative case when it is embedded in an accusative and infinitive clause) and the gerund in the bare ablative case. The subject of the non-finite verb is coreferential with that of the main verb, and it is not repeated in the adjunct clause. The meaning of the bi-clausal construction is mainly compositional, insofar as it combines the meaning of the main clause, that of the adjunct clause, and the semantic relation between them. In (1), the present participial clause expresses the circumstances accompanying the main state of affairs. In (2), the gerundial clause expresses the manner by which the main state of affairs is realized. Adjunct clauses are syntactically optional constituents, and hence they can be omitted without making the sentence ungrammatical or nonsensical.

The Romance progressive construction, illustrated for Spanish, Italian, and French in respectively (9), (10), and (11), is a mono-clausal construction headed by a verbal periphrasis containing a verb of existence (9), position (10), or movement (11) as the auxiliary and a gerund (9-10) or verbal form in -ant (11) as the main verb (Squartini 1998, 38; 73). ${ }^{2}$

(9) Estuvo escribiendo hasta despues del alba.

"He was writing until after dawn."

(10) Ieri Giulio stava parlando con Marco, quando arrivò Giacomo.

"Yesterday Giulio was talking to Marco, when Giacomo came."

(11) Les prix vont augmentant.

"The prices are rising."

The verb of existence, position, or movement functions as a grammatical marker of the progressive aspect, insofar as it presents the non-finite state of affairs "in its uninterrupted duration or continuity" (Garey 1957, 91). The gerund or verbal form in -ant is the

${ }^{2}$ In Spanish and Italian, the gerund has been generalized as the main verb of the progressive construction at the expense of the present participle. In French, the gerund and the present participle have merged morphologically in the verbal form in -ant (Buridant 2000, 237). 
semantic and syntactic main verb, and hence the argument structure of the verbal periphrasis corresponds to that of the gerund or verbal form in -ant.

Since new constructions emerge through the functional and formal reanalysis of existing constructions, the constructionalization of the progressive construction implies, among other things, that the verb of existence, position, or movement becomes reanalyzed as an auxiliary. The evolution of a verb from the status of a lexical main verb to that of an auxiliary corresponds to a grammaticalization process (Heine 1993, 53-66). Therefore, the hypothesis that some Latin instances of the pattern [verb of existence/position/movement + present participle/gerund] qualify as progressive constructions will be confirmed if the verbs of existence, position, and movement show signs of a grammaticalized status as markers of the progressive aspect.

According to Heine (1993, 54-56), the grammaticalization of verbs into temporal, aspectual, or modal markers is a slow and gradual process in which four linguistic shifts succeed each other in a fixed order: a semantic shift (desemanticization), a morphosyntactic shift (decategorization), a morphophonological shift (cliticization), and a phonetic shift (erosion). These shifts are each individually slow and gradual as well, so that grammaticalizing verbs can be more or less desemanticized, decategorized, cliticized, and eroded. The extent to which Latin instances of the pattern [verb of existence/position/movement + present participle/gerund] qualify as progressive constructions will now be investigated by determining the degree of grammaticalization of the verbs of existence, position, and movement used in this pattern. For reasons of space, the discussion will focus on the qualitative analysis of the examples in (3-8), which largely suffice to postulate the existence of the Latin progressive construction.

\section{The degree of grammaticalization of the verbs of existence, position, and movement}

\subsection{Desemanticization}

The first shift in a grammaticalization process is a semantic shift, and is referred to as "desemanticization" (Heine 1993, 54). It is the process in which "in specific contexts a lexical item is emptied of its lexical semantics and acquires a grammatical function" (Heine $1993,54)$. According to Heine $(2002,86)$, the acquisition of a grammatical function is a slow and gradual process in which four stages succeed each other. At stage I, the linguistic item is used with its source meaning, irrespective of the discourse context within which it is used. At stage II, it is used in a discourse context ("bridging context") which gives rise to a pragmatic inference that is typically favored at the expense of its source meaning. At stage III, the linguistic item is used in a discourse context ("switch context") which is incompatible with its source meaning, so that the pragmatically inferred interpretation is the only possible one. At stage IV, the pragmatic inference turns into the new meaning of the linguistic item. This new meaning conventionalizes and does no longer need to be supported by the discourse context that gave rise to it.

The desemanticization of a linguistic item being a slow and gradual process, the four stages of Heine's model do not succeed each other in an abrupt way, but rather form "a continuum leading from stage I to stage IV and beyond" (Heine 2002, 86). As such, the source and target meaning of grammaticalizing items may co-exist, generating a situation 
of layering (Hopper 1991, 22). Grammaticalizing items may keep track of their source meaning even at an advanced stage of their grammaticalization process, a phenomenon that is referred to by Hopper $(1991,22)$ as "persistence". I will now determine the degree of desemanticization of the verbs of existence, position, and movement that are combined with a present participle or gerund.

The verbs of existence have a maximal degree of desemanticization, insofar as their source meaning is excluded in practically all instances. In (3) and (6), the function of erat is not to express the existence of a rivulet or Darius, in which case the present participle currens and the gerunds vociferando and congregando would function as the predicate of an adjunct clause expressing the circumstances accompanying the existence of a rivulet ('a rivulet existed to the right of Caesar's troops while it was running on swampy soil') or Darius ('Darius existed on the mountain while he was screaming and gathering many enemies').

Instead, erat functions as a grammatical marker of the progressive aspect: it scopes over the lexical meaning of the present participle currens and the gerunds vociferando and congregando, and presents the states of affairs denoted by them in their "uninterrupted duration or continuity" (Garey 1957, 91) (Aalto 1949, 75; Bertinetto 2000, 562-563; Bertinetto et al. 2000, 538-540; Haverling 2010, 492-497). The running of the rivulet and Darius' screaming and gathering of enemies are presented as continuous activities whose beginning and ending are suspended.

This analysis of erat applies to all verbs of existence used in combination with a present participle or gerund that are cited in the literature, irrespective of whether they belong to Republican and Classical Latin or Late and Early Medieval Latin. Some more examples are given in (12-14).

(12) Primus esses memoriter progeniem vostram usque ab avo atque atavo proferens. (Ter. Phorm. 394-395 [2nd c. BC])

"You would have been the first to recite your lineage right from your grandfather and your grandfather's grandfather by heart."

(13) [...] invenerunt speluncam, quam sequentes fuerunt forsitan per passus centum. (Eger. Itin. $14,6[4$ th c.AD])

"They found a cave, which they have been following for about a hundred steps."

(14) Et statim aperti sunt oculi eius, et erat admirans cernensque magnalia Dei [...]. (Greg. Hist. $6[6$ th c. AD])

"His eyes opened immediately, and he was admiring and contemplating the wonders of God."

The verbs of position and movement do not have a maximal degree of desemanticization, insofar as their source meaning often co-exists with their target meaning. However, their interpretation as lexical verbs without any progressive value is unlikely in most instances, especially when taking into account the discourse context within which they are used.

When the pattern [verb of position/movement + present participle/gerund] is interpreted independently of the discourse context within which it is used, the verbs of position can usually be interpreted with their source meaning. In (4) and (7), stat and stetit can express that Aristaeus stands near the water and that the general stood near a forest, 
in which case the present participle lacrimans and the gerund cunctando function as the predicate of an adjunct clause expressing the circumstances accompanying the standing still of Aristaeus ('Aristaeus is standing near the waters of our father while he is crying') or the general ('the general stood near a forest for some time while he was hesitating'). In (5) and (8), ibat and vadunt can express that a thief and some people are moving around, in which case the present participle vociferans and the gerund mentiendo function as the predicate of an adjunct clause that expresses the circumstances accompanying the movement of a thief ('the thief was continuously moving while he was shouting') or some people ('against those who move around while they lying').

However, when the pattern [verb of position/movement + present participle/gerund] is interpreted within its discourse context, there emerges a pragmatic inference that typically overrides the source meaning of the verb of position or movement. In order to demonstrate this, the passages in (4), (7), (5), and (8) are integrated in their broader discourse context in respectively (15-18).

(15) Carmine quo captae dum fusis mollia pensa devolvunt, iterum maternas impulit auris luctus Aristaei, vitreisque sedilibus omnes obstipuere; sed ante alias Arethusa sorores prospiciens summa flavum caput extulit unda et procul: "O gemitu non frustra exterrita tanto Cyrene soror, ipse tibi, tua maxima cura tristis Aristaeus nostri genitoris ad undam stat lacrimans, et te crudelem nomine dicit." (Verg. Georg. 4, 348-356 [1st c. AD])

"And while, charmed by the strain, they unrolled the soft coils from their spindles, again the wail of Aristaeus smote upon his mother's ear, and all upon their crystal thrones were startled. Yet, first of all the sisters, Arethusa, looking forth, raised her golden head above the water's brim, and cried from afar: "O sister Cyrene, you are not alarmed by this loud lament in vain. Aristaeus, your own beloved, is sadly crying near the waters of our father, and he says that you are cruel by name."'

(16) Emensaque aestimatione decimi lapidis cum prope silvam venisset squalore tenebrarum horrendam, stetit dux diu cunctando, indicio perfugae doctus per subterranea quaedam occulta fossasque multifidas latere plurimos, ubi habile visum fuerit erupturos. (Amm. Hist. 17, 1, $8[4$ th c. AD])

"After having advanced approximately ten miles, when he had come near a forest formidable with its forbidding shade, the general had been hesitating for some time, being informed by the report of a deserter that large forces were lurking in some hidden underground passages and wide-branching trenches, ready to burst forth when they saw an opportunity."

(17) Igitur non post multos hos dies ille fur arreptus est a nequissimo daemonio. Ille vero ibat incessanter vociferans hoc illi accidisse ob scelere quod in servum sancti Trudonis perpetrasset. (Vita Trudonis 26 [8th c. AD])

"So not many days later this thief was caught by a worthless demon. He was truly continuously shouting that this had happened to him because of the crime that he completed against the servant of saint Trudo."

(18) Ut missi sive comites illorum missos transmittunt contra illos qui mentiendo vadunt, ut eos convincant. (Carol. capit. 1a, 810 [9th c. AD]) 
"As the legates or their officials send around messengers against those who are lying, in order to convince them."

In (15), the lamenting of Aristaeus is at the center of the passage. It is expressed not only by the present participle lacrimans, but also by the nouns luctus and gemitu. It is the lamentations of Aristaeus that trigger the attention of Arethusa and her sisters, and which causes Arethusa to investigate what is going on. In (16), the narrator zooms in on a particular state of affairs occurring near a forest after a general and his army have marched ten miles, and when the general has just been told that enemies are lurking and waiting for an opportunity to attack. It is the hesitations of the general that is being focused on, insofar as he is trying to figure out what to do about the threat of the enemy. In (17), the shouting of the thief is at the center of the passage. After being caught by a demon, the thief was continuously shouting that this had happened to him because of the crime that he completed against the servant of saint Trudo. In (18), the lying of some people is at the center of the passage. Legates or their officials are sending around messengers in order to convince the people who are spreading lies.

Within these contexts, the verbs of position and movement primarily function as grammatical markers of the progressive aspect: they scope over the lexical meaning of the present participles lacrimans (15) and vociferans (17) or the gerunds cunctando (16) and mentiendo (18), and present the state of affairs denoted by them in their "uninterrupted duration or continuity" (Garey 1957, 91) (Aalto 1949, 75; Bertinetto 2000, 562-563; Bertinetto et al. 2000, 538-540; Haverling 2010, 492-497). Admittedly, Aristaeus may be standing while he is lamenting and the general may be standing while he is hesitating, but they can just as well be sitting, lying, or pacing around. Similarly, the thief may be moving around while he is shouting and the people may be moving around while they are telling lies, but they can just as well be sitting, lying, or standing still. What matters is that Aristaeus is lamenting, that the general has been hesitating, that the demon has been shouting, and that some people have been spreading lies for quite some time, the question whether they are standing still or moving around being less relevant.

This analysis of stat/stetit and ibat/vadunt applies to most verbs of position and movement used in combination with a present participle or gerund that are cited in the literature, irrespective of whether they belong to Republican and Classical Latin or Late and Early Medieval Latin. Some more examples with a verb of position are given in (1921 ) and with a verb of movement in (22-24) (Aalto 1949, 75; Haverling 2010, 497).

(19) Stabant etiam principes sacerdotum et scribae constanter accusantes eum. (Vulg. Luc. 23, 9-10 [4th c. AD])

"The chief priests and the scribes were constantly accusing him."

(20) Cumque dixisset mihi sermonem istum steti tremens. (Vulg. Dan. 10, 11 [4th c. AD).

"When he spoke this word to me, I had been trembling."

(21) Quae fidei merito nunc stat spargendo medelas corpora multa medens [...]. (Ven. Fort. carm. 5, 17, 5-6 [6th c. AD])

"By the power of faith he is now spreading cures and healing many bodies."

(22) Et locupletatus est homo et ibat proficiens atque succrescens donec magnus vehementer effectus est. (Vulg. Gen. 26, 13 [4th c. AD]) 
"And the man became rich, and he was prospering and growing until he became very wealthy."

(23) $[\ldots]$ credas ut stellas ire trahendo comas. (Ven. Fort. carm. 5, 5, 118 [6th c. AD])

"You would believe that stars are dragging their rays."

(24) [...] congregasti socios tuos et vadis pugnando et dissipando civitates. (Leo Alex. 1, 40 [10th c. $\mathrm{AD}])$

"You have gathered your allies and you are fighting and destroying cities."

In sum, the verbs of existence, position, and movement that are combined with a present participle or gerund have all three a desemanticized status, but the degree of desemanticization of the verbs of existence is higher than that of the verbs of position and movement. The verbs of position and movement do achieve a maximal degree of desemanticization, but only in the individual Romance languages.

The desemanticized status of the verbs of existence, position, and movement implies that they can no longer function as the semantic main verb of the pattern in which they are used. We will now see that they have equally lost their ability to function as the syntactic main verb of this pattern.

\subsection{Decategorization}

The second shift in a grammaticalization process is a morphosyntactic shift, and is referred to as "decategorization" (Heine 1993, 54-55). It is the process in which linguistic items gradually lose (some of) the morphological and syntactic properties of their morphosyntactic category (Hopper 1991, 22; Heine 1993, 55). There are different ways in which verbs that grammaticalize into temporal, aspectual, or modal markers can show signs of a decategorized status, such as the loss of their argument structure and their ability to function as the predicate of an independent sentence (Marchese 1986, 82; Heine 1993, 23; 55). These two properties will now be applied to the verbs of existence, position, and movement that are combined with a present participle or gerund.

Used with their lexical source meaning, verbs of existence, position, and movement select two arguments: verbs of existence and position require a subject and a temporal or spatial argument, while verbs of movement require a subject and a spatial or manner argument. Now, the loss of the argument structure of the verbs of existence and position used in combination with a present participle or gerund cannot be detected in their subject argument, insofar as their subject is coreferential with that of the present participle or gerund and not exposed to selection restrictions, so that it cannot be determined with certainty whether it is governed by the verb of existence or position or the present participle or gerund. By contrast, the loss of the argument structure of the verbs of movement can be detected in their subject argument, inasmuch as their subject is exposed to the selection restriction [+animate]. Examples like (23), in which the subject corresponds to the inanimate noun stellas, indicate that the verb of movement has lost at least part of its argument structure, although a metaphorical interpretation and hence a non-violation of the selection restriction is not excluded. Verbs of movement do become used with inanimate subjects that are incompatible with a metaphorical interpretation and hence the non-violation of the selection restriction [+animate], but only in Romance, as evidenced by the French example in (12). 
As for the second argument of the verbs of existence, position, and movement that are combined with a present participle or gerund, in theory it allows two analyses: one as the argument of the verb of existence, position, or movement, which is in this case interpreted with its source meaning, and one as the adjunct of the present participle or gerund, in which case the verb of existence, position, or movement is interpreted with its target meaning. However, the source meaning of the verbs of existence is excluded in practically all instances $(\$ 5.1 .1)$, and that of the verbs of position and movement is typically backgrounded in favor of their target meaning ( $\$$ 5.1.2). Therefore, the temporal, spatial, or manner constituents are almost undoubtedly analyzed as adjuncts of the present participle or gerund. This is clearly the case for the spatial constituents ad dextrum, nostri genitoris ad undam, and in monte in (3), (4), and (6), and for the temporal constituents incessanter, diu, and constanter in (5), (7), and (19). Moreover, in several instances the temporal, spatial, or manner constituent can hardly be taken as the argument of the verb of existence, position, or movement for purely semantic reasons. Witness the spatial constituent forsitan per passus centum in (13). Also, in many instances there is no temporal, spatial, or manner constituent at all. This is the case with the verbs of existence esses and erat in (12) and (14), and with the majority of the verbs of movement, such as vadunt, ibat, ire, and vadis in (8), (22), (23), and (24).

The second way in which the verbs of existence, position, and movement that are combined with a present participle or gerund show signs of a decategorized status is by the loss of their ability to function as the predicate of a grammatical and meaningful sentence in the absence of the present participial or gerundial clause. Prototypical or non-decategorized finite verbs can function as the predicate of a simple, independent clause, and hence the clauses headed by them and accompanied by an adjunct clause can be isolated as grammatical and meaningful simple sentences, adjunct clauses being semantically and syntactically optional constituents. In (1) and (2), the sentence remains indeed grammatical and meaningful in the absence of the present participial clause hoc sperans and the gerundial clause cunctando. This does not hold for the instances of the pattern [verb of existence/position/movement + present participle/gerund]. In the absence of a temporal, spatial, or manner constituent that could function as the second argument of the verb of existence, position, or movement, the omission of the present participial or gerundial clause makes the sentence nonsensical, if not ungrammatical. In the presence of such a constituent, the omission of the present participial or gerundial clause does not make the sentence ungrammatical, but it forces the verb of existence, position, or movement to be interpreted with its source meaning. However, the source meaning of the verbs of existence is excluded in practically all instances $(\$ 5.1 .1)$, and that of the verbs of position and movement is typically backgrounded in favor of their target meaning (\$5.1.2).

In sum, the verbs of existence, position, and movement that are combined with a present participle or gerund have all three a decategorized status, but the degree of decategorization of the verbs of existence is slightly higher than that of the verbs of position and movement, just like their degree of desemanticization. The decategorized status of the verbs of existence, position, and movement implies that they can no longer function as the syntactic main verb of the pattern in which they are used. We will now see that they have also lost their syntactic independency. 


\subsection{Cliticization}

The third shift in a grammaticalization process is a morphophonological shift, and is referred to as "cliticization" (Heine 1993, 55-56). It is the process in which a linguistic item develops into an operator of another item, so as to become part of its morphophonological structure (Heine 1993, 55). There are different ways in which verbs that grammaticalize into temporal, aspectual, or modal markers can show signs of a cliticized status, such as the loss of their ability to be properly negated (Brinton 1988, 70-71; Park 1992, 17; Heine 1993,23 ; 56). This factor will now be applied to the verbs of existence, position, and movement that are combined with a present participle or gerund.

Prototypical or non-cliticized verbs functioning as the predicate of a clause that is accompanied by an adjunct clause can be properly negated. In (1) and (2), the main verbs educit and restituit can indeed be negated independently of the present participial or gerundial clause, as shown in (25) and (26).

(25) Hoc sperans legiones tres ex castris non educit. (negated version of Caes. civ. 1, 43, 3 [1st c. $\mathrm{BC}])$

"Hoping for this, he did not lead three legions out of camp."

(26) Unus homo nobis cunctando non restituit rem. (negated version of Cic. off. 1, 84 [1st c. $\mathrm{BC}])$

"One man did not restore the state for us by delaying."

By contrast, in all instances of the pattern [verb of existence + present participle/gerund], the insertion of a negative operator cannot affect the verb of existence independently of the present participial or gerundial clause. That is, the negative operator cannot have scope on the verb of existence alone; rather it scopes on its combination with the present participial or gerundial clause. In the negated versions of (3) and (6), it is the continuous running of the rivulet (27) and Darius' continuous shouting and gathering of enemies (28) that are negated, not the existence of a rivulet or Darius, even when the negative operator immediately precedes the verb of existence.

(27) Palustri et voraginoso solo currens non erat ad dextrum. (negated version of Bell. Hisp. 29, $2[1$ st c. BC])

"To the right the rivulet was not running on swampy soil full of bog-holes."

(28) In monte non erat Darius vociferando et congregando multitudinem hostium. (negated version of Leo Alex. 2, 14 [10th c. AD])

"Darius was not screaming and gathering many enemies on the mountain."

In other words, (27) and (28) cannot mean that a rivulet and Darius do not exist, but that they are running or shouting and gathering enemies.

As for the instances of the pattern [verb of position/movement + present participle/ gerund], the insertion of a negative operator can affect the verb of position or movement independently of the present participial or gerundial clause, but this forces the verb of position or movement to be interpreted with its source meaning. However, the source meaning of these verbs is typically backgrounded in favor of their target meaning, so that the 
negation most likely affects the combination of the verb of position or movement and the present participial or gerundial clause. The most plausible interpretation of the negated versions of (4), (5), (7), and (8), is indeed that Aristaeus is not continuously crying (29), that the general was not continuously hesitating (30), that the thief was not continuously shouting (31), and that the people is not continuously lying (32), even when the negative operator precedes the verb of position or movement.

(29) Aristaeus nostri genitoris ad undam non stat lacrimans. (negated version of Verg. Georg. 4, 355-356 [1st c. BC])

"Aristaeus is not crying by the waters of our father."

(30) Non stetit dux diu cunctando. (negated version of Amm. Hist. 17, 1, 8 [4th c. AD])

"The general had not been hesitating for some time."

(31) Ille non ibat incessanter vociferans. (negated version of Vita Trudonis 26 [8th c. AD])

"He (the thief) was not continuously shouting."

(32) Contra illos qui mentiendo non vadunt. (negated version of Carol. capit. 1a, 810 [9th c. AD])

"Against those who are not lying."

In other words, it is unlikely that (29) and (30) mean that Aristaeus and the general are not standing still, but that they are crying or hesitating. In a similar vein, it is unlikely that (31) and (32) mean that the thief and some people are not moving around, but that they are shouting or spreading lies.

In sum, the verbs of existence, position, and movement that are combined with a present participle or gerund have all three a cliticized status, but the degree of cliticization of the verbs of existence is higher than that of the verbs of position or movement, just like their degree of desemanticization and decategorization. The cliticized status of the verbs of existence, position, and movement implies that in the pattern [verb of existence/position/movement + present participle/gerund], they have not only lost their status as the semantic and syntactic main verb $(\$ 5.1-\$ 5.2)$, but also their syntactic independency. This is strong evidence in favor of their analysis as auxiliarized grammatical markers scoping over the lexical semantics of the present participle or gerund.

\subsection{Erosion}

The fourth and final shift in a grammaticalization process is a phonetic shift, and is referred to as "erosion" (Heine 1993, 56). It is the process in which linguistic items lose their phonological substance and their ability to carry distinctive tone or stress (Heine $1993,56)$. In the absence of spoken records of Latin, signs of this shift are difficult to detect. Nevertheless, it is reasonable to assume that under normal semantic and pragmatic circumstances, the verbs of existence, position, or movement that are combined with a present participle or gerund do not carry stress, just like their Romance descendants or any other auxiliary verb (Akmajian et al. 1979, 53; Heine 1993, 23). 


\subsection{Conclusion}

In most instances of the pattern [verb of existence/position/movement + present participle/gerund], the verb of existence, position, or movement shows signs of a desemanticized, decategorized, cliticized, and possibly eroded status. It can therefore be rightfully assumed that they are at least to some extent grammaticalized, so that the formal and functional properties of the pattern within which they are used resemble those of the Romance progressive construction more than those of the bi-clausal constructions in (1) and (2). There are thus strong arguments in favor of the analysis of the Latin pattern [verb of existence/position/movement + present participle/gerund] as a construction in its own right, although its constructionalization process is far from being completed, especially when the marker of the progressive aspect corresponds to a verb of position or movement. The progressive construction completes its constructionalization process only in the Romance languages, but the part of this process that has taken place already in Latin is much more important than has traditionally been assumed. Further arguments in favor of the existence of the Latin progressive present participle/gerund construction will be presented in $\$ 6$.

It needs to be emphasized that the existence of the Latin progressive construction does not imply that all instances of the pattern [verb of existence/position/movement + present participle/gerund] qualify as such. Quite the contrary, some instances of this pattern still instantiate the source construction of the Latin progressive construction. For instance, in (33) the contextually most plausible interpretation of stare is as a lexical verb of position, not as a marker of the progressive aspect.

(33) Et postea sic debet in casa sua intrare et de quatuor angulos terrae pulverem in pugno colligere debet, et sic postea in duropello, hoc est in limitare, stare debet, intus in casa respiciens, et sic de sinistra manu de illa terra trans scapulas suas iactare super illum, quem proximio rem parentem habet. (Pactus legis Salicae 58, 2 [6th c. AD])

"And thereafter he should enter his house and collect dust from its four corners in his hand, and then he should stand on the duropello, that is, on the threshold, while looking into the house, and then with his left hand he should throw the earth over his shoulders onto him who is his nearest relative."

The passage in (33) contains a series of instructions that murderers have to perform in their house when they cannot pay their composition. After having collected dust, they need to stand on the threshold with their face turned and throw the dust over their shoulders. Within this context, stare clearly has its source meaning, the present participial clause intus in casa respiciens functioning as an adjunct clause specifying the way in which murderers should stand on the threshold of their house. The fact that the murderers need to stand on the threshold of their house is indeed of key interest in this official ritual, and hence stare cannot be analyzed as a grammatical marker of the progressive aspect.

Put differently, the emergence of the Latin progressive construction does not eradicate the bi-clausal construction from which it has emerged. Rather, the source construction continues to exist alongside its target construction, giving rise to a situation of layering (cf. Hopper 1991, 22) that persists even in the individual Romance languages.

In Latin, the progressive present participle construction is much more frequent than the progressive gerund construction. Moreover, the progressive present participle con- 
struction occurs already in Republican and Classical Latin, while the progressive gerund construction is confined to Late and Early Medieval Latin. Progressive constructions with a verb of movement do not occur in Republican and Classical Latin, but only in Late and Early Medieval Latin (Aalto 1949, 75). The exact relation between the progressive present participle construction and the progressive gerund construction has not been investigated so far, and it also falls outside the scope of the present paper. However, since they have more or less the same functional and formal properties, the progressive present participle construction and the progressive gerund construction seem to qualify as what Cappelle $(2006,18)$ calls "allostructions", viz. "variant structural realizations of a construction that is left partially underspecified".

\section{The propagation of the Latin progressive construction}

Diachronic Construction Grammar is a usage-based theory of language change, insofar as it is claimed that new constructions emerge as a result of how speakers actually use language in specific communicative settings (Croft 2000; 2001; Bybee 2010, 9; Traugott \& Trousdale 2013, 21; Traugott 2015, 53; 55). The frequency of an innovation (Bybee 1985; 2010) and especially its successful transmission into the speech community (Croft 2000, 5; Traugott 2015, 53; 55) play a crucial role in this respect, because "innovations made by individual users do not count as changes; only those that are replicated, transmitted to other users, and therefore conventionalized, do so" (Traugott 2015, 53). Language is used in an innovative way when the hearer interprets a construction in a way that does not match the interpretation of the speaker (Croft 2001; Heine 2002, 86; Traugott 2015, 55). An innovation is propagated when the hearer deliberately reuses the construction with its new interpretation as a speaker rather than a hearer (Traugott 2015, 55). The more an innovation is propagated in the speech community, the more speakers are familiarized with it, and the higher are its odds to have a high frequency. The frequency of an innovation thus depends on its degree of propagation in the speech community. However, the frequency of an innovation is more than just the outcome of its degree of propagation in the speech community. It influences the pace of language change: the more frequently an innovation is used by individual speakers, the higher are its odds to be spread more quickly to other speakers and to increase its overall frequency, which, in turn, increases the odds for language change to obtain more quickly. In other words, the prerequisite for language change is the successful propagation of an innovation in the speech community, not its high frequency (Mair 2004; Traugott 2015, 66). As it turns out, language change may occur even when the innovation has a low frequency: the English "going to + infinitive construction" has grammaticalized in the expression of the future tense already in the first decades of the 17th c., despite its very low frequency in this period (Mair 2004).

Since the prerequisite for language change is the successful propagation of an innovation in the speech community rather than its high frequency, the fact that the Latin progressive construction has a low frequency throughout the history of Latin and slightly gains in frequency only in Late and Early Medieval Latin, especially after Gregory of Tours and in Merovingian Latin (Haverling 2010, 496), does not exclude its analysis as a construction in its own right. It rather explains why its constructionalization process has taken such a long period of time, and why it has not been completed within Latin, but only in the individual Romance languages. 
However, given that the prerequisite for language change is the successful propagation of an innovation in the speech community, the analysis of the Latin progressive construction as a construction in its own right can only be confirmed if it can be shown that the construction has successfully spread in the Latin speech community. This is clearly the case, insofar as the construction appears in texts that show a very large diasystematic variation.

From a diachronic perspective, the Latin progressive appears throughout the history of Latin. It is very rare in Republican and Classical Latin $(3-4,12)$, and gains in frequency only in Late and Early Medieval Latin (5-8, 13-14, 19-24), but unambiguous instances are found already in the work of Terence (12). From a diatopic perspective, the Latin progressive constructions appears in texts written by authors who were born and have spent their lives in many different regions of (what has become) the Roman Empire, such as Virgil (4), Ammianus Marcellinus (7), Terence (12), Egeria (13), Gregory of Tours (14), and Venantius Fortunatus $(21,23)$. From a diastratic perspective, the texts containing Latin progressive constructions are written by authors whose degree of education ranges from rather low, such as Egeria (13) and the anonymous writers of the Spanish War (3) and the Vulgate (19-20, 22), to very high, such as Virgil (4) and Gregory of Tours (14). From a diaphasic perspective, the Latin progressive construction appears not only in literary texts (or texts with a literary function), such as Terence's Phormio (12) and Virgil's Georgics (4), but also in non-literary texts (or texts with a non-literary function), such as Egeria's Peregrinatio Egeriae (13) and the Vulgate (19-20, 22). Moreover, Latin progressive constructions appear not only in prosaic texts, such as the Spanish War (3) and Ammianus Marcellinus' Histories (7), but also in poetic texts, such as Terence's Phormio (12) and Virgil's Georgics (4). Finally, the texts containing Latin progressive constructions belong to different textual domains (e.g. religious, historiographical, literary, and legal) and genres (e.g. hagiography, historiography, epic poems, itinerary, tragedy, comedy, and formulae).

There is thus good evidence that the Latin progressive construction has successfully spread in the speech community, which confirms its analysis as a construction in its own right. The fact that the construction is particularly frequent in Christian texts and translations from the Bible may be influenced by Greek, as has traditionally been assumed, but it clearly cannot be considered the exclusive property of Ecclesiastic Latin (Amenta 2003, 146-148; Haverling 2010, 495-496).

\section{General conclusion}

In the present study, I have shown that the functional and formal properties of many instances of the Latin pattern [verb of existence/position/movement + present participle/ gerund] are very similar to those of the Romance progressive construction. In particular, the verbs of existence, position, and movement show signs of a desemanticized, decategorized, cliticized, and possibly eroded status, which causes them to be semantically and syntactically reanalyzed as grammatical markers of the progressive aspect. The shift of the verbs of existence, position, and movement from the status of the semantic and syntactic main verb to that of an auxiliary deprives them of their syntactic independency, which causes them to form a verbal periphrasis with the present participle or gerund, which, as for it, shifts from the status of the predicate of an adjunct clause to that of the semantic and syntactic main verb. However, the degree of grammaticalization of the verbs of position 
and movement is lower than that of the verbs of existence due to the persistence of (at least part of) their lexical source meaning (cf. Hopper 1991, 22).

Although the degree of grammaticalization of the verbs of existence, position, and movement is sufficiently high for the pattern [verb of existence/position/movement + present participle/gerund] to qualify as a construction in its own right, they do not have reached a maximal degree of grammaticalization within Latin. Consequently, the constructionalization of the progressive construction has not been completed within Latin, but only in the individual Romance languages. This might explain why the emergence of the progressive construction has not been investigated within the field of Latin linguistics.

The results of this paper are based on the qualitative analysis of a varied, but restricted number of Latin instances of the pattern [verb of existence/position/movement + present participle/gerund]. Hence it would be interesting to complete these results by means of a diachronic corpus study, whose quantitative results could give more insight into the functional and formal properties of the Latin progressive construction at the different stages of its constructionalization process.

\section{References}

Aalto P. Untersuchungen über das lateinische Gerundium und Gerundivum. Helsinki, Suomalainen Tiedeakatemia, 1949.

Akmajian A., Steele S. M., Wasow T. The Category AUX in Universal Grammar, Linguistic Inquiry 1979, 10, 1-64.

Amenta L. Perifrasi aspettuali in greco e in latino. Origini e grammaticalizzazioni. Milan, FrancoAngeli, 2003.

Barðdal J., Gildea S. Diachronic Construction Grammar: Epistemological Context, Basic Assumptions and Historical Implications, in: J. Barðdal, E. Smirnova, L. Sommerer, S. Gildea (eds) Diachronic Construction Grammar. Amsterdam, Benjamins, 2015, 1-50.

Barðdal J., Smirnova E., Sommerer L., Gildea S. (eds) Diachronic Construction Grammar. Amsterdam, Benjamins, 2015.

Bertinetto P. M. The Progressive in Romance, as compared with English, in: Ö. Dahl (ed.) Tense and Aspect in the Languages of Europe. Berlin, De Gruyter, 2000, 559-604.

Bertinetto P. M., Ebert K., de Groot C., Dahl Ö. The Progressive in Europe, in: Ö. Dahl (ed.) Tense and Aspect in the Languages of Europe. Berlin, De Gruyter, 2000, 517-558.

Brinton L. The Development of English Aspectual Systems. Aspectualizers and Post-Verbal Particles. Cambridge, Cambridge University Press, 1988.

Buridant C. Grammaire nouvelle de l'ancien français. Paris, SEDES, 2000.

Bybee J. Morphology. A Study of the Relation between Meaning and Form. Amsterdam, Benjamins, 1985.

Bybee J. Language, Usage and Cognition. Cambridge, Cambridge University Press, 2010.

Cappelle B. Particle Placement and the Case for 'Allostructions'. Constructions 2006, 7, 1-28.

Croft W. Explaining Language Change. An Evolutionary Approach. London, Longman, 2000.

Croft W. Radical Construction Grammar: Syntactic Theory in Typological Perspective. Oxford, Oxford University Press, 2001.

Eklund S. The Periphrastic, Completive and Finite Use of the Present Participle in Latin. With Special Regard to Translations of Christian Texts in Greek up to 600 A. D. Uppsala, Acta Universitatis Upsaliensis, 1970.

Garey H. Verbal Aspect in French. Language 1957, 33 (2), 91-110.

Goldberg A. Constructions: A Construction Grammar Approach to Argument Structure. Chicago, University of Chicago Press, 1995.

Goldberg A. Constructions at Work: The Nature of Generalization in Language. Oxford, Oxford University Press, 2006.

Haverling G. Actionality, Tense, and Viewpoint, in: P. Baldi, P. Cuzzolin (eds) New Perspectives on Historical Latin Syntax. Vol. 2: Constituent Syntax: Adverbial Phrases, Adverbs, Mood, Tense. Berlin, De Gruyter, 2010, 277-523.

Heine B. Auxiliaries, Cognitive Forces and Grammaticalization. Oxford, Oxford University Press, 1993. 
Heine B. On the Role of Context in Grammaticalization, in: I. Wischer, G. Diewald (eds). New Reflections on Grammaticalization. Amsterdam, Benjamins, 2002, 83-101.

Hilpert M. Constructional Change in English. Developments in Allomorphy, Word Formation, and Syntax. Cambridge, Cambridge University Press, 2013.

Hopper P. On Some Principles of Grammaticization, in: E. C. Traugott, B. Heine (eds) Approaches to Grammaticalization. Amsterdam, Benjamins, 1991, 17-36.

Lehmann C. Towards a typology of clause linkage, in: J. Haiman, S. A. Thompson (eds) Clause Combining in Grammar and Discourse. Amsterdam, Benjamins, 1988, 181-225.

Mair C. Corpus Linguistics and Grammaticalisation Theory: Statistics, Frequencies, and Beyond, in: H. Lindquist, C. Mair (eds). Corpus Approaches to Grammaticalization in English. Amsterdam, Benjamins, 2004, 121-150.

Marchese L. Tense/Aspect and the Development of Auxiliaries in Kru languages. Arlington, The Summer Institute of Linguistics, 1986.

Park I. Constituency Problems in the Auxiliary Verb Construction in Burmese. Manuscript, University of Oregon, Eugene, 1992.

Pinkster H. Narrative Tenses in Merovingian Hagiographic Texts, in: J.Herman (ed.) La transizione dal latino alle lingue romanze. Atti della tavola rotonda di linguistica storica. Università Ca' Foscari di Venezia, 14-15 giugno 1996. Tübingen, Max Niemeyer Verlag, 1988, 229-235.

Rosenbach A. How Synchronic Gradience Makes Sense in the Light of Language Change (and vice versa), in: E.C.Traugott, G.Trousdale (eds) Gradience, Gradualness and Grammaticalization, Amsterdam, Benjamins, 2010, 149-179.

Squartini M. Verbal Periphrases in Romance: Aspect, Actionality, and Grammaticalization. Berlin, De Gruyter, 1998.

Traugott E. C. Toward a coherent account of grammatical constructionalization, in: J. Barðdal, E. Smirnova, L. Sommerer, S. Gildea (eds). Diachronic Construction Grammar. Amsterdam, Benjamins, 2015, 51-79.

Traugott E. C., Trousdale G. Gradience, Gradualness and Grammaticalization. How do they Intersect?, in: E. C. Traugott, G. Trousdale (eds). Gradience, Gradualness and Grammaticalization, Amsterdam, Benjamins, 2010, 19-44.

Traugott E. C., Trousdale G. Constructionalization and Constructional Changes. Oxford, Oxford University Press, 2013.

Vangaever J. Le gerundium et le participe présent en latin classique: perspectives typologiques, De Lingua Latina. Revue de linguistique latine du Centre Alfred Ernout (en ligne) 2018, 15, 1-42.

Vester E. Manner and Instrument Expressions in Latin. Assen, Van Gorcum, 1983.

Received: April 14, 2019

Accepted: October 12, 2019 